\title{
Differential Expression of Proinflammatory Cytokines and Their Inhibitors during the Course of Meningococcal Infections
}

\author{
Marcel van Deuren, Johanna van der Ven-Jongekrijg, \\ Pierre N. M. Demacker, Anton K. M. Bartelink, \\ Roelof van Dalen, Robert W. Sauerwein, Harald Gallati, \\ James L. Vannice, and Jos W. M. van der Meer
}

\begin{abstract}
Deparments of Internal Medicine. Intensive Care, and Medical Microbiologv. University Hospital Nijmegen, and Deparment of Internal Medicine, Eemland Hospital. Amersfoort. Netherlands; F. Hoffmann-La Roche Lid., Pharmaceutical Research. Basel, Switzerland: Synergen Inc..
\end{abstract}

Boulder. Colorado

\begin{abstract}
Circulating concentrations of tumor necrosis factor- $\alpha$ (TNF), interleukin (IL)-1 $\beta$, IL-6, IL-1 receptor antagonist (IL-1 ra), and soluble TNF receptors p55 (sTNFr-55) and p75 (sTNFr-75) and ex vivo production of TNF, IL-1, IL-6, and IL-1 ra using a whole blood culture system were measured during the acute and convalescent stages of meningococcal infection. Circulating TNF and IL-1 were below detection level, whereas IL-6 and IL-1 ra, sTNFr-55, and sTNFr-75 were increased at admission. The ex vivo production of proinflammatory cytokines TNF, IL-1, and IL-6 was suppressed at admission and restored gradually during recovery. On the contrary, the production of the antiinflammatory IL-1 ra was increased at admission. The elevated concentrations of both IL-1 ra and sTNFr early in the course of infection suggest a regulatory role for these antiinflammatory compounds. The observed down-regulation of the ex vivo production of TNF, IL-1, and IL-6 and up-regulation of the production of IL-1 ra in the acute stage may indicate a protective regulation mechanism.
\end{abstract}

On contact with gram-negative bacteria or endotoxin (lipopolysaccharide, LPS), the immune-apparatus responds with the production of a broad spectrum of cytokines. After injection of LPS in human volunteers, the plasma concentrations of the proinflammatory cytokines tumor necrosis factor- $\alpha$ (TNF), interleukin (IL)- $1 \beta$, and IL- 6 and the antiinflammatory $\mathrm{IL}-1$ receptor antagonist ( $\mathrm{L}-\mathrm{I}$ ra) rapidly increase [ $1-3]$. Furthermore, the plasma concentrations of soluble TNF receptors p55 (sTNFr-55) and p75 (sTNFr-75) also rise [4, 5].

Proinflammatory cytokines are thought to be essential for an adequate host defense. However, excessive production of TNF and IL-I causes shock, and high plasma concentrations of TNF, IL-1, and IL-6 are associated with high mortality rates [6-10]. This deleterious action of the proinflammatory cytokines is balanced by STNFr and IL-1ra. Soluble TNF receptors prevent the inflammatory effects of TNF by binding to TNF. High STNFr/TNF plasma ratios were found to be associated with a better prognosis [5, 11]. IL- I ra blocks the proinflammatory action of IL- 1 by competitive binding to the $I L-1$ receptor [12]; infusion of $I L-1$ ra in experimental shock prevents the shock and improves survival [13-15]. A high production of IL-l ra during the acute stage of an infection may therefore be beneficial.

Received 26 May 1993: revised I September 1993.

Financial support: Merck Sharp \& Dohme. Netherlands.

Reprints or correspondence: Dr. Marcel van Deuren, Dept. of Internal Medicine. University Hospital Nijmegen. P.O. Box 9101, 6200 HB Nijmegen. Netherlands.

The Journal of Infectious Diseases 1994;169:157-61 (C) 1994 by The University of Chicago. All rights reserved. $0022-1899 / 94 / 6901-0022 \$ 01.00$
The principle sources of these cytokines are blood monocytes and tissue macrophages. On incubation with LPS, isolated monocytes or whole blood taken from healthy donors produce ex vivo cytokines in a spectrum similar to that observed after LPS injection in volunteers. Without LPS stimulation, there is no or minimal ex vivo cytokine production $[16,17]$. Several investigators have reported that during the acute stage of serious infections, the ex vivo production of TNF and IL-1 is depressed [18-21]. The cause of this impaired production is unknown, but it has been considered as a down-regulated state of the cytokine-producing cells, possibly reflecting a protective mechanism by averting high concentrations of these cytokines $[19,21]$. This hypothesis would be supported if the production of the antiinflammatory cytokine IL-1 ra were inversely regulated and increased during the acute stage.

We describe the pattern of circulating TNF, IL-1, IL-6, IL-1 ra, sTNFr-55, and sTNFr-75 and the ex vivo production of TNF, IL-I, IL-6, and IL-1 ra during meningococcal infection.

\section{Patients and Methods}

Five patients with bacteriologically proven acute meningococcal infections, admitted to our intensive care unit, were studied. Four patients had meningitis without severe hemodynamic complications, and 1 (patient 2) had mild sepsis without meningitis. Some clinical parameters indicating the severity of disease and prognosis are summarized in table 1 . All patients received antibiotics. Dexamethasone was given in different doses over 1-7 days (table 1). Patient 2 was also treated with two exchange transfusions [22]. All patients recovered completely, except patient 3 who developed sensorineural deafness. 
Table 1. Characteristics of the patients with meningococcal infections at admission and their dexamethasone therapy.

\begin{tabular}{|c|c|c|c|c|c|c|c|c|}
\hline $\begin{array}{l}\text { Patient no.. } \\
\text { sex/age (years) }\end{array}$ & $\begin{array}{l}\text { Disease period } \\
\text { before } \\
\text { hospitalization } \\
\text { (h) }\end{array}$ & $\begin{array}{c}\text { Blood } \\
\text { pressure } \\
\text { (mm Hg) }\end{array}$ & $\begin{array}{c}\text { Arterial } \mathrm{HCO}_{3}^{-} \\
\text {concentration } \\
(\mathrm{mmol} / \mathrm{L})\end{array}$ & $\begin{array}{l}\text { Leukocytes in } \\
\text { cerebrospinal } \\
\text { fluid }\left(\times 10^{6} / \mathrm{L}\right)\end{array}$ & $\begin{array}{l}\text { Leukocytes in } \\
\text { peripheral blood } \\
\left(\times 10^{9} / \mathrm{L}\right)\end{array}$ & $\begin{array}{c}\text { Plasma } \\
\text { endotoxin } \\
\text { concentration } \\
(\mathrm{pg} / \mathrm{mL})\end{array}$ & $\begin{array}{c}\text { Duration } \\
\text { (days) }\end{array}$ & $\begin{array}{c}\text { Dose } \\
(\mathrm{mg} / \mathrm{kg} / \text { day })\end{array}$ \\
\hline 1. $F / 3$ & 18 & $100 / 55$ & 20.0 & 24.320 & 30.9 & $<12.5$ & 3.5 & 1.000 \\
\hline 2. $F / 5$ & 16 & $80 / 50$ & 16.9 & 11 & 7.3 & 162 & 4 & 0.600 \\
\hline 5. $F / 20$ & 24 & $120 / 78$ & 15.3 & 13,500 & 29.8 & 283 & 1 & 0.130 \\
\hline
\end{tabular}

Serial plasma and serum samples were collected shortly after admission and daily for 6 days. For endotoxin measurements, 2 $\mathrm{mL}$ of blood was drawn into 5-mL pyrogen-free plastic vials (Falcon; Becton Dickinson Labware, Lincoln Park, NJ) containing 50 IU of pyrogen-free heparin and centrifuged at $200 \mathrm{~g}$ for $10 \mathrm{~min}$. Plasma for cytokine assays was drawn into 4-mL tubes (Vacutainer System; Becton Dickinson, Rutherford, NJ) containing $48 \mu \mathrm{L}$ of $15 \% \operatorname{EDTA}\left(\mathrm{K}_{3}\right)$ and $250 \mu \mathrm{L}$ of aprotinin (10,000 kallikrein-inactivating units/mL; Bayer, Leverkusen, Germany). The tubes were centrifuged immediately at $2250 \mathrm{~g}$ for $10 \mathrm{~min}$ and then at $15,000 \mathrm{~g}$ for $5 \mathrm{~min}$ to remove the platelets. For IL-6 measurements serum was used. Aliquots were stored at $-20^{\circ} \mathrm{C}$ until assay.

The ex vivo production of cytokines was measured in whole blood using similar 4-mL tubes [23]. One tube was incubated without LPS; in the other, $50 \mu \mathrm{L}$ of LPS (final concentration, 10 $\mu \mathrm{g} / \mathrm{mL}$; Escherichia coli O55:B5; Sigma, St Louis) was added under sterile conditions. After 24 h of incubation at $37^{\circ} \mathrm{C}$, both tubes were centrifuged and handled as described above.

Endotoxin was measured in platelet-rich plasma by a chromogenic limulus amoebocyte lysate assay (KabiVitrum, Stockholm). TNF was determined by RIA as described by Van der Meer et al. [24] (detection level, $100 \mathrm{pg} / \mathrm{mL}$ ). IL-1 was measured by RIA according to Lisi et al. [25] without chloroform extraction (detection level, $80 \mathrm{pg} / \mathrm{mL}$ ). IL-6 was measured by ELISA as delineated by Barrera et al. [26] (detection level, 20 $\mathrm{pg} / \mathrm{mL}$ ). IL-I ra was determined by RIA according to Poutsiaka et al. [17] (detection level, $300 \mathrm{pg} / \mathrm{mL}$ ). sTNFr were measured by an enzyme-linked immunobinding assay (Hoffmann-La Roche; detection level, $80 \mathrm{pg} / \mathrm{mL}$ for sTNFr- 55 and $300 \mathrm{pg} / \mathrm{mL}$ for STNFr-75); normal values measured in 19 healthy volunteers were $1470 \pm 190 \mathrm{pg} / \mathrm{mL}$ (median \pm SD) for STNFr-55 and $2520 \pm 660 \mathrm{pg} / \mathrm{mL}$ for sTNFr-75. To minimize analytical errors, all samples from the same patient were analyzed in the same run in duplicate.

\section{Results}

Circulating cytokines and sTNFr. The plasma concentrations of TNF and IL- I were below detection level in all samples. At admission, IL-6 (range, 365-2550 pg/mL; median, 860 ). IL-I ra (range, 2840-4680 pg/mL; median, 3740), sTNFr-55 (range, 2782-5215 pg/mL; median, 3873), and sTNFr-75 (range, 5700-17282 pg/mL; median, 12910) were increased (figure 1). Within 2 days, these concentrations fell to normal levels.

Ex vivo cytokine production. The ex vivo production of TNF without LPS stimulation was below detection level in all samples. With LPS stimulation, TNF production was below detection level during the acute stage of the disease. After 3 days, during convalescence, this production gradually recovered to $810-3430 \mathrm{pg} / \mathrm{mL}$ (median, 2260) at day 6 (figure 2).

The course of IL-1 production showed a similar pattern: no measurable production at admission and restored LPSstimulated production during recovery at day 6 (range, 945$4300 \mathrm{pg} / \mathrm{mL}$; median, 2325).

IL-6 was detectable at admission in unstimulated and in LPS-stimulated tubes. However, after correction for the circulating serum concentrations, the ex vivo production of IL6 at admission was negligible. Similar to the pattern of ex vivo production of TNF and IL-1, the LPS-stimulated production of IL-6 was restored during recovery, reaching 165$9000 \mathrm{pg} / \mathrm{mL}$ (median, 2850) at day 6.

The ex vivo production of IL- I ra followed a different pattern. At admission, the production of IL- I ra in both unstimulated and LPS-stimulated cultures appeared to be increased. The concentration at day 0 in the unstimulated tubes ranged from 4450 to $6510 \mathrm{pg} / \mathrm{mL}$ (median, 5570); in the LPS-stimulated tubes, this was $7080-12,990 \mathrm{pg} / \mathrm{mL}$ (median, 11,140). The LPS-stimulated production decreased during the next 2 days toward a stable median of $6710 \mathrm{pg} / \mathrm{mL}$ from day 2 to day 6 . The unstimulated production declined gradually toward a median of $1140 \mathrm{pg} / \mathrm{mL}$ at days 4-6.

The ex vivo production of sTNFr was not measured because previous studies demonstrated that TNF receptors were only minimally released in the whole blood culture system on LPS stimulation (data not shown).

A similar pattern of ex vivo production was observed in all patients, regardless of their leukocyte number or corticosteroid dose. Thus, the observed pattern in ex vivo cytokine production was not influenced by these parameters.

\section{Discussion}

We followed the concentrations of circulating cytokines and their ex vivo production during the course of meningo- 
Figure 1. Circulating cytokine concentrations and their inhibitors during course of disease. Tumor necrosis factor- $\alpha$ (TNF) and interleukin (IL)-1 $\beta$ were below detection levels (respectively, 100 and $80 \mathrm{pg} / \mathrm{mL}$ ) in all samples and therefore are not shown. Left: patterns of IL-6(-) and IL-1 receptor antagonist (O). Right: courses of soluble TNF receptors p55 (O) and p75 (O). Median values have been interpolated.

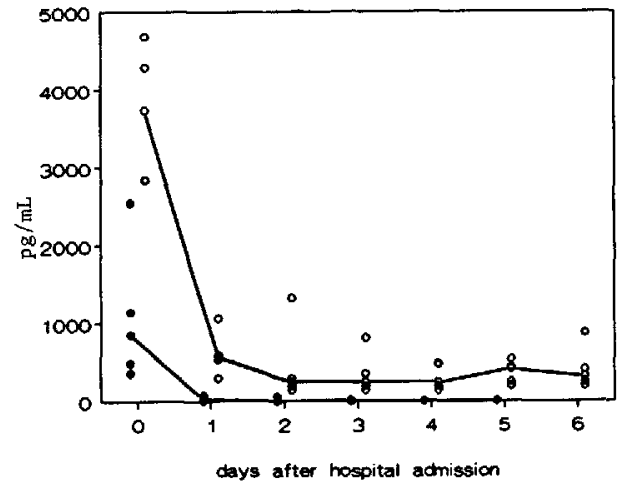

coccal infections. The onset of acute meningococcal infections is abrupt, with a rather short disease period before hospitalization. As such. meningococcal infections resemble experimental models using endotoxin challenge.

In our patients, circulating TNF and IL-I concentrations were all below detection level. Several factors may be responsible for this negative finding. It may be possible that we missed the initial cytokinemia. The disease period before admission ranged from 16 to $36 \mathrm{~h}$, and it is known that after LPS injection in human volunteers, TNF and IL-1 levels peak within 90-180 min $[1,2]$. From clinical studies, we know that high TNF concentrations occur early during severe meningococcal infections [8-10]. The relatively low endotoxin concentrations at admission, the good prognostic score, and the absence of shock in 4 of the 5 patients may also explain the low TNF and IL-1 concentrations [8-10,27, 28]. Finally, a slight increase in TNF and IL-1 could have been missed because of the relatively high detection level of our assays. Recently, we have been able to detect rapidly declining TNF and IL-I concentrations early in the course of very severe and lethal meningococcal disease (unpublished data). In the present series, actual activation of the cytokine network was documented by elevated concentrations of IL6. Furthermore, the increased sTNFr- 55 and sTNFr- 75 levels are compatible with TNF activity on target cells in tissues, because binding of TNF to its receptors on these cells leads to shedding of the extramembranous part of the receptor [5, 29]. IL-1 ra concentrations were also elevated during the acute stage. The high concentrations of both STNFr and ILI ra early in the course of the infection suggest a regulating role for these antiinflammatory compounds.

The LPS-stimulated ex vivo production of the proinflammatory cytokines TNF, IL-1, and IL-6 was suppressed during the acute stage. Gradually the production capacity was restored during reconvalescence. In contrast, the capacity to produce ex vivo IL-1 ra was regulated inversely (figure 2). The LPS-stimulated IL-1 ra production was maximal during the acute stage and reached stability after 2 days. Moreover, in the unstimulated cultures at admission, a spontaneous production of IL-1 ra was observed, which gradually decreased during convalescence.

We used a whole blood culture system to measure the ex vivo cytokine production. In vitro studies with isolated peripheral blood mononuclear cells (PBMC) or monocytes
Figure 2. Ex vivo cytokine production of tumor necrosis factor- $\alpha$ (TNF), interleukin (IL)-1 $\beta$, IL-6 and $I L-1$ receptor antagonist $(1 \mathrm{~L}$ I ra) during course of disease. Left: median concentrations $(n=5)$ in whole blood cultures after $24 \mathrm{~h}$ ex vivo incubation without lipopolysaccharide (LPS) stimulation. Right: median concentrations after incubation with $10 \mu \mathrm{g} / \mathrm{mL}$ LPS.
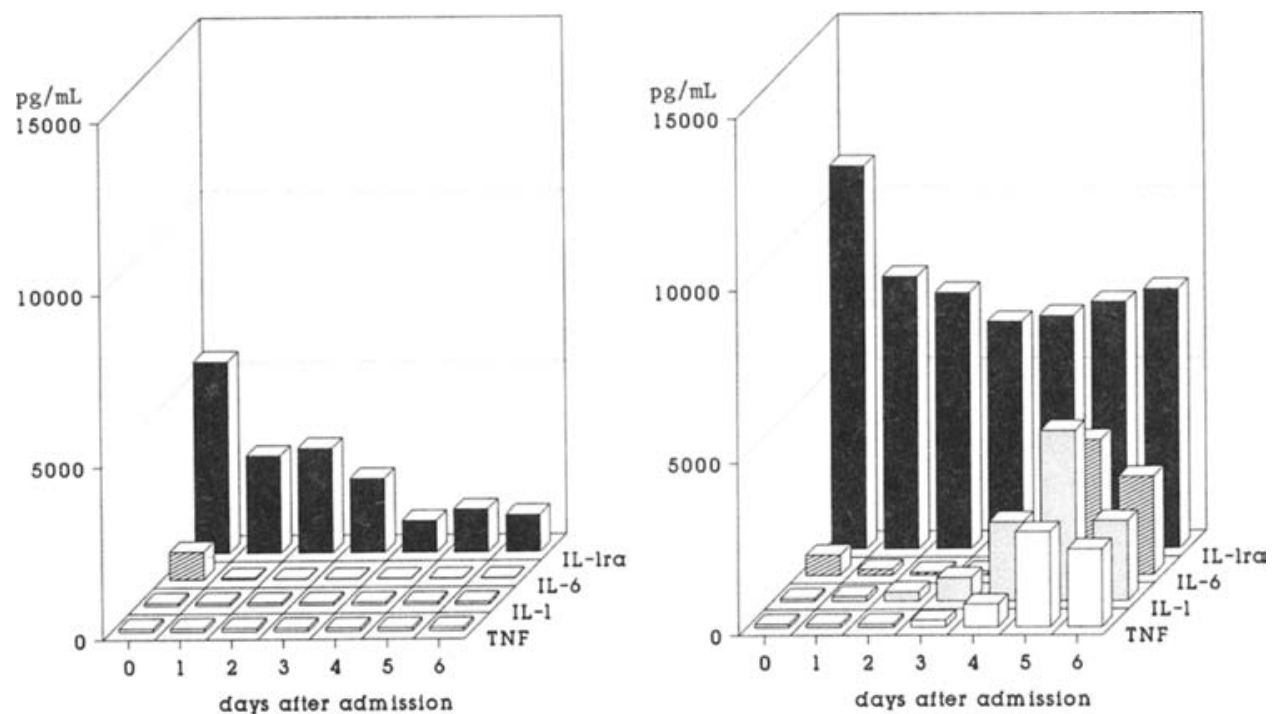
have yielded a substantial part of our knowledge of the cytokine response to infectious stimuli. However, isolation of PBMC requires large blood volumes and is laborious and difficult to organize. Whole blood culture systems are a suitable alternative in these circumstances [23,30-32]. In addition, the whole blood system represents the cytokine response of all types of cells present in blood at a certain time point and may therefore be a more realistic assessment than measurements using a fixed number of isolated and cultured cells.

Impaired ex vivo production of the proinflammatory cytokines TNF and IL-1 during acute infection has been reported by others [18-21]. Our study confirms these observations but also shows that the impaired capacity to produce proinflammatory cytokines does not indicate that the cells present in blood are completely refractory in terms of cytokine production. Rather, they seem to have switched from a mainly proinflammatory action (as in healthy individuals) to an antiinflammatory action. During recovery, the cells gradually switch again to the balanced proinflammatory status.

Further research should be done on the mechanism behind this programmed switch. Our findings in meningococcal infection may represent a process similar to endotoxin tolerance, the phenomenon that survival in experimental animals is markedly increased if a lethal dose of endotoxin is preceded by a smaller dose. Inhibition of the production of TNF, IL-1, and IL-6 is regarded as crucial [33]. Similarly, in human volunteers receiving endotoxin intravenously, the ex vivo production by $\mathrm{CD} 14^{+}$cells of TNF, IL- 1 , and IL- 6 is significantly decreased [34]. IL-4 and IL-10 may play a role in this process. IL-10 and IL-4 both down-regulate the LPSstimulated production by human PBMC and monocytes of TNF, IL-1, and IL-6, whereas preincubation with IL-4 increases the synthesis of IL-1 ra [35-37]. Better insight into these regulatory mechanisms may enable us to understand why in some patients the invasion in the bloodstream of Neisseria meningitidis induces high plasma concentrations of TNF, IL-1, and IL-6 with severe shock, whereas in others a localized meningitis develops with low systemic concentrations of these cytokines $[8-10]$. Further study on these regulatory mechanisms may provide new therapeutic interventions.

In conclusion, antiinflammatory compounds such as sTNFr and IL- 1 ra are present in the circulation during early meningococcal infection. The down-regulation of the production of TNF, IL-I, and IL-6 and up-regulation of the production of IL-1 ra during acute infection could serve as a mechanism of protection.

\section{Acknowledgments}

We thank G. R. Adolph (Boehringer, Vienna) for the TNF $\alpha$, P. Graber (Glaxo, Geneva) for the IL-1 $\beta$, D. Boraschi (Sclavo,
Sienna, Italy) for the anti-IL-1 $\beta$ antibodies, and C. A. Dinarello for the anti-IL-I ra antibodies.

\section{References}

1. Hesse DK, Tracey KJ, Fong $Y$, et al. Cytokine appearance in human endotoxemia and primate bacteremia. Surg Gynecol Obstet 1988:166:147-53.

2. Cannon JG. Tompkins RG, Gelfland JA, et al. Circulating interleukin1 and tumor necrosis factor in septic shock and experimental fever. $J$ Infect Dis 1990;161:79-84.

3. Granowitz EV. Santos AA. Poutsiaka DD. et al. Production of interleukin- 1 receptor antagonist during experimental endotoxaemia. Lancet 1991:2:1423-4.

4. Spinas GA, Keller U, Brockhaus M. Release of soluble receptors for tumor necrosis factor (TNF) in relation to circulating TNF during experimental endotoxinemia. J Clin Invest 1992;90:533-6.

5. Van Zee KJ, Kohno T, Fischer E. Rock CS, Moldawer LL. Lowry SF. Tumor necrosis factor soluble receptors circulate during experimental and clinical inflammation and can protect against excessive tumor necrosis factor $\alpha$ in vitro and in vivo. Proc Natl Acad Sci USA 1992;89:4845-9.

6. Michie HR, Spriggs DR, Manogue KR, et al. Tumor necrosis factor and endotoxin induce similar metabolic responses in human beings. Surgery $1988 ; 104: 280-5$.

7. Okusawa S. Gelfand JA, Ikejima T, Connolly RJ, Dinarello CA. Interleukin 1 induces a shock-like state in rabbits. Synergism with tumor necrosis factor and the effect of cyclooxygenase inhibition. J Clin Invest 1988;81:1162-72.

8. Waage A. Halstensen A, Espevik T. Association between tumor necrosis factor in serum and fatal outcome in patients with meningococcal disease. Lancet 1987:1:355-7.

9. Girardin E, Grau GE. Dayer JM. Roux-Lombard P. J5 Study Group. Lambert PH. Tumor necrosis factor and interleukin-l in the serum of children with severe infectious purpura. N Engl J Med 1988;319: 397-400.

10. Waage A, Brandtzaeg P, Halstensen A, Kierulf P. Espevik T, The complex pattern of cytokines in serum from patients with meningococcal septic shock. Association between interleukin 6. interleukin I, and fatal outcome. J Exp Med 1989;169:333-8.

11. Girardin E. Roux-Lombard P, Grau GE, et al. Imbalance between tumor necrosis factor- $\alpha$ and soluble TNF receptor concentrations in severe meningococcaemia. Immunology 1992;76:20-23.

12. Dinarello CA, Thompson RC. Blocking IL-1: interleukin-I receptor antagonist in vivo and in vitro. Immunol Today 1991;12:404-10.

13. Alexander HR, Doherty GM, Buresh CM, Venzon DJ, Norton JA. A recombinant human receptor antagonist to interleukin 1 improves survival after lethal endotoxemia in mice. I Exp Med 1991;173: 1029-32.

14. Wakabayashi G. Gelfland JA. Burke JF, Thompson RC. Dinarello CA. A specific receptor antagonist for interleukin 1 prevents Escherichia coli induced shock in rabbits. FASEB J 1991;5:338-43.

15. Fischer E. Marano MA. Van Zee KJ, et al. Interleukin-I receptor blockade improves survival and hemodynamic performance in Escherichia coli septic shock, but fails to alter host responses to sublethal endotoxemia. J Clin Invest 1992:89:1551-7.

16. Schindler R, Mancilla J, Endres S, Ghorbani, Clark SC, Dinarello CA. Correlations and interactions in the production of interleukin- 6 ( $\mathrm{IL}-$ 6). $\mathrm{IL}-1$ and tumor necrosis factor (TNF) in human blood mononuclear cells: IL-6 suppresses IL-1 and TNF. Blood 1990;75:40-7.

17. Poutsiaka DD, Clark BD, Vannier E, Dinarello CA. Production of interleukin- 1 receptor antagonist and interleukin- $1 \beta$ by peripheral blood mononuclear cells is differentially regulated. Blood 1991;78: 1275-81. 
18. Luger A. Graf H. Schwarz HP, Stummvoll HK, Luger TA. Decreased serum interleukin 1 activity and monocyte interleukin 1 production in patients with fatal sepsis. Crit Care Med 1986:14:458-61.

19. Helminen $M$. Vesikari T. Interleukin-1 production in bacterial meningitis. Scand J Infect Dis 1990:22:105-8.

20. Simpson SQ, Modi H, Balk RA, Bone RC. Casey LC. Reduced alveolar macrophage production of tumor necrosis factor during sepsis in mice and man. Crit Care Med 1991;19:1060-6.

21. Helminen M. Interleukin-1 production from peripheral blood monocytes in septic infections in children. Scand J Infect Dis 1991; 23:607-11.

22. Van Deuren M, Santman FW, Van Dalen R, Sauerwein RW, Span LFR, Van der Meer JWM. Plasma exchange and whole blood exchange in meningococcal sepsis. Clin Infect Dis 1992;15:424-30.

23. Nerad JL, Griffiths K, Van der Meer JWM, et al. Interleukin-1 $\beta$ (IL$1 \beta$ ). IL-1 receptor antagonist. and TNF $\alpha$ production in whole blood. J Leukoc Biol 1992:52:687-92.

24. Van der Meer JWM, Endres S, Lonnemann G, et al. Concentrations of immunoreactive human tumor necrosis factor alpha produced by human mononuclear cells in vitro. $J$ Leukoc Biol 1988;43:16-23.

25. Lisi PJ, Chu CW, Koch GA, Endres S, Lonnemann G. Dinarello CA. Development and use of radio immunoassay for human interleukin13. Lymphokine Res 1987;6:229-44.

26. Barrera P, Boerbooms AMT, Janssen EM, et al. Circulating soluble tumor necrosis factor receptors, interleukin-2 receptors. tumor necrosis factor $\alpha$, and interleukin- 6 levels in rheumatoid arthritis. Longitudinal evaluation during methotrexate and azathioprine therapy. Arthritis Rheum 1993:36:1070-9.

27. Brandtzaeg P, Kierulf P, Gaustad P, et al. Plasma endotoxin as a predictor of multiple organ failure and death in systemic meningococcal disease. J Infect Dis 1989;159:195-204.
28. Gedde-Dahl TW, Bjark P, Hølby A, Høst JH, Bruun JN. Severity of meningococcal disease: assessment by factors and scores and implications for patient management. Rev Infect Dis 1990;12:973-92.

29. Lantz M. Malik S. Slevin ML. Olsson I. Infusion of tumor necrosis factor (TNF) causes an increase in circulating TNF-binding protein in humans. Cytokine 1992;2:402-6.

30. Van der Ven-Jongekrijg J, Demacker PMN, Van der Meer JWM. A simple method for measuring cytokine production in vitro [abstract]. Cytokine 1991;3:495.

31. Finch-Arietta MB, Cochran FR. Cytokine production in whole blood ex vivo. Agents Actions 1991;34:49-52.

32. Wilson BMG, Severn A, Rapson NT, Chana J, Hopkins P. A convenient human whole blood culture system for studying the regulation of tumor necrosis factor release by bacterial lipopolysaccharide. J Immunol Methods 1991; 139:233-40.

33. Mengozzi M. Ghezzi P. Cytokine down-regulation in endotoxin tolerance. Eur Cytokine Netw 1993;4:89-98.

34. Granowitz EV, Porat R. Mier JW, et al. Intravenous endotoxin suppresses the cytokine response of peripheral blood mononuclear cells of healthy humans. J Immunol 1993; 151:1637-45.

35. De Waal Malefijt R, Abrams J, Bennet B, Figdor CG, De Vries JE. Interleukin 10 (IL-10) inhibits cytokine synthesis by human monocytes: an autoregulatory role of IL-10 produced by monocytes. J Exp Med 1991:174:1209-20.

36. Te Velde AA. Huijbens RJ. Heije K. De Vries JE. Figdor CG. Interleukin-4 (IL-4) inhibits secretion of IL-1 beta. tumor necrosis factor alpha, and IL-6 by human monocytes. Blood 1990;76:1392-7.

37. Vannier E, Miller LC, Dinarello CA. Coordinated antiinflammatory effects of interleukin 4: interleukin 4 suppresses interleukin 1 production but up-regulates gene expression and synthesis of interleukin 1 receptor antagonist. Proc Natl Acad Sci USA 1992;89:4076-80. 